\title{
Pengaruh lama pemasakan daging anjing terhadap sifat mutu organoleptik
}

\author{
J. Lahiwu, J.E.G. Rompis*, S.E. Surtijono, M.R. Tinangon \\ Fakultas Peternakan Universitas Sam Ratulangi Manado, 95115 \\ *Korespondensi (corresponding author): jegronne@yahoo.co.id
}

\begin{abstract}
ABSTRAK
Tujuan penelitian ini untuk mengetahui pengaruh lama pemasakan daging anjing terhadap sifat mutu organoleptik. Bahan yang digunakan daging anjing jantan yang berumur 14 bulan yang diambil bagian paha sebanyak $3 \mathrm{~kg}$ dan bumbu/rempah, 4 perlakuan yang di uji dalam penelitian ini yaitu, P1: 60 menit pemasakan, P2: 80 menit pemasakan, P3: 100 menit pemasakan, P4: 120 menit pemasakan. percobaan ini menggunkan Rancangan Acak Lengkap (RAL) dan dinilai oleh 40 orang panelis untuk menentukan sifat organoleptik lama pemasakan daging anjing. Pengukuran data organoleptik menggunakan skala hedonik yang terdiri dari variabel warna, aroma, keempukan, tekstur, citarasa, untuk menentukan perbedaan perlakuan dilakukan dengan uji DMRT. Hasil penelitian ini menunjukkan bahwa perlakuan memberikan pengaruh yang sangat nyata $(\mathrm{P}<0,01)$ terhadap warna, aroma, keempukan, tekstur, citarasa daging anjing. Kesimpulannya adalah berdasarkan sifat mutu organoleptik secara keseluruhan lama pemasakan daging anjing dapat diterima namun lama pemasakan 120 menit lebih disukai dan diterima oleh panelis.
\end{abstract}

Kata kunci: Lama Pemasakan, Daging Anjing, organoleptic

\begin{abstract}
THE EFFECT OF THE DURATION OF COOKING DOG MEAT ON ORGANOLEPTIC QUALITY PROPERTIES. The purpose of this study was to determine the effect of cooking time on dog meat on its organoleptic qualities. The ingredients used were male dog meat aged 14 months, The meat dog was taken from the thigh as much as $3 \mathrm{~kg}$ and spices, four treatments were tested in this study, namely, P1: 60 minutes of cooking, P2: 80 minutes of cooking, P3: 100 minutes of cooking, P4: 120 minutes of cooking. This experiment used a completely randomized design (CRD) and was assessed by 40 panelists to determine the organoleptic properties of the cooking time dog meat. Measurement of organoleptic data using a hedonic scale consisting of variables of color, aroma, tenderness, texture, teste, to determine differences in treatment was carried out by the DMRT test. The results of this study indicated that the treatment had a very significant effect $(\mathrm{P}<0,01)$ on the color, aroma, tenderness, texture, and taste of dog meat- the condusion is based on the organoleptic quality characteristics, overall cooking time of dog meat is acceptable, but cooking time of 120 minutes is preferred and accepted by the panelists.
\end{abstract}

Keywords: Cooking time, Dog meat, Organoleptic 


\section{PENDAHULUAN}

Masyarakat Minahasa sebagian besar gemar mengkonsumsi masakan khas yaitu RW, yang diolah berasal dari daging anjing Anjing yang dipilih hanyalah anjing yang memiliki bulu yang halus atau tipis dan mempunyai bulu yang berwarna kuning kecoklatan. Istilah RW berasal dari kata rintek wuuk yang artinya bulu halus dan makanan ini bagi masyarakat Minahasa dianggap mampu menunjang ketahanan pangan dan menambah pendapatan masyarakat.

Di Indonesia terdapat empat kota yang mengkonsumsi masakan olahan dari daging anjing antara lain Manado, dikenal dengan masakan RW, Karo Sumatera Utara daging anjing dipanggang dan dibuat sup daging anjing, di Bali daging anjing dibuat sate RW dan rawon daging anjing, di Jakarta daging anjing dimasak seperti di Manado dan Karo yaitu dimasak RW, dipanggang dan sup daging (Anggreani, 2018).

Salah satu proses pengolahan masakan dari bahan mentah sampai bisa dikonsumsi adalah dengan menggunakan suhu dan lama pemasakan. Demikianpula dengan masakan bumbu RW perlu pengolahan untuk menjadi masakan. Adapun bumbu/rempah yang digunakan dalam pemasakan daging anjing antara lain bawang merah, bawang putih, cabai rawit, daun bawang, jahe, lengkuas, serai atau sereh, daun pandan, daun kemangi, daun lemon suangi, garam $(\mathrm{NaCl}), \mathrm{MSG}$, minyak kelapa. Tinangon et al. (2014) menyatakan bahwa pengunaan bumbu/rempah pada umumnya akan meningkatkan aroma dan citarasa pada pangan olahan. Menurut Lumbong et al. (2017) bahwa tujuan pemasakan adalah untuk menyatuhkan bahan, memberi rasa empuk sehingga siap untuk di konsumsi. Bumbu/rempah sangat berperan penting dalam menentukan citarasa suatu makanan yang disukai, serta aman untuk dikonsumsi oleh masyarakat
(Rompis dan Komansilan, 2014). Pada pemasakan daging anjing belum memiliki data ilmiah tentang berapa lama waktu yang cocok untuk pemasakan daging anjing. Proses pemasakan sangat menentukan nilai akseptabilitas dari sebuah produk pangan. Itulah sebabnya dilakukan penelitian yang bertujuan untuk mengetahui pengaruh lama pemasakan daging terhadap sifat mutu organoleptik.

\section{MATERI DAN METODE PENELITIAN}

\section{Tempat penelitian}

Penelitian ini dilakasanakan di Laboratorium Teknologi Hasil Ternak Fakultas Peternakan Universitas Sam Ratulangi Manado.

\section{Materi penelitian}

Bahan-bahan yang digunakan dalam penelitian ini yaitu: daging anjing jantan yang berumur 14 bulan yang diambil paha bagian belakang, bumbu/rempah terdiri, $300 \mathrm{~g}$ lengkuas, $200 \mathrm{~g}$ jahe, $400 \mathrm{~g}$ bawang merah, $400 \mathrm{~g}$ batang sereh, $200 \mathrm{~g}$ bawang putih, $600 \mathrm{~g}$ daun bawang, $800 \mathrm{~mL}$ minyak goreng, 18 lembar daun pandan, 600 g cabai rawit, 30 lembar daun lemon suangi, $100 \mathrm{~g}$ daun kemangi, $20 \mathrm{sdm}$ cap tikus, $75 \mathrm{~g}$ MSG, $60 \mathrm{~g}$ garam, $600 \mathrm{~mL}$ air.

\section{Alat}

Peralatan yang digunakan yang digunakan dalam pemasakan antara lain: pisau, blender, sendok makan, wadah, timbangan, spatula, wajan, kompor gas, termometer.

Peralatan yang digunakan untuk uji organoleptik antara lain: wadah sample yang diberi nomor kode, format uji, pensil, penghapus, tusuk gigi, air mineral serta ketimun.

\section{Metode penelitian}




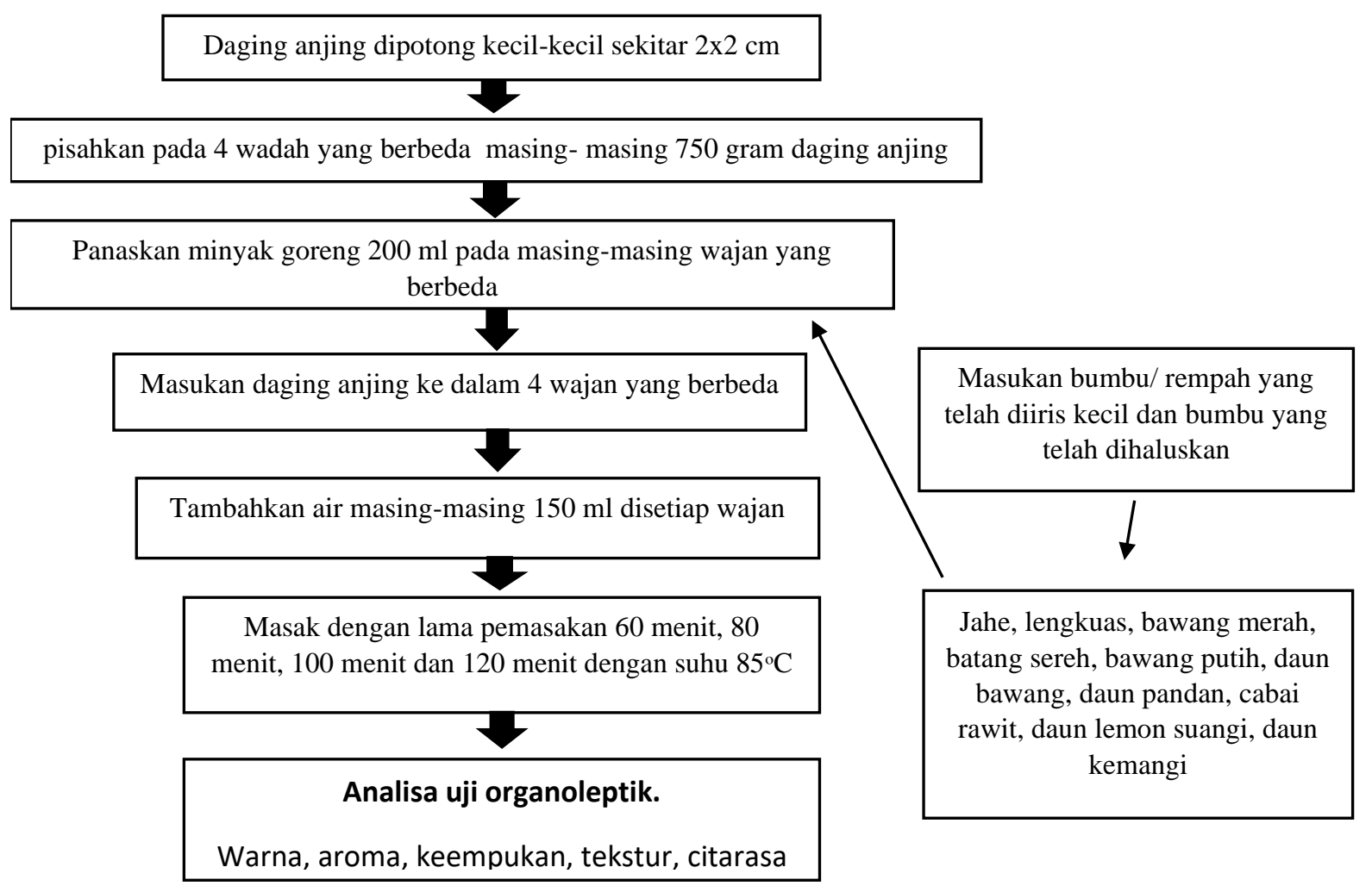

Gambar 2. Skema Pemasakan Daging Anjing

Penelitian ini menggunakan metode Rancangan Acak Lengkap (RAL) (Steel dan Torrie (1991). Untuk uji mutu organoleptik menggunakan skala hedonik dengan 4 perlakuan dan 40 ulangan (panelis), perlakuan disusun sebagai berikut:

P1: 60 menit pemasakan

P2: 80 menit pemasakan

P3: 100 menit pemasakan

P4: 120 menit pemasakan

Perlakuan ini menggunakan suhu pemasakan yang sama yakni $85^{\circ} \mathrm{C}$

\section{Prosedur penelitian}

Daging anjing dibersihkan, kemudian di potong-potong kecil dengan ukuran $2 \times 2$ $\mathrm{cm}$ dan dipisahkan pada empat wadah masing-masing $750 \mathrm{~g}$, panaskan minyak goreng ke dalam setiap wajan setelah panas masukan daun pandan yang di iris halus, daun lemon suangi, setelah kelihatan layu dan harum masukkan bumbu-bumbu yang digiling halus seperti lengkuas, sereh, jahe, bawang putih, bawang merah, cabai rawit, aduk sampai bumbu-bumbu tersebut harum dan setelah harum masukkan daging anjing yang telah di potong-potong kecil pada empat wadah yang berbeda aduk sampai bumbu tercampur, tambahkan air, diamkan sampai daging lunak apabila air sudah kering masukkan garam dan MSG dan angkat ketika waktu 60 menit, 80 menit, 100 menit, 120 menit, dengan suhu pemasakan yang sama yaitu $85^{\circ} \mathrm{C}$ yakni untuk mencapai tingkat kematangan Well 
Done, masakkan daging siap diuji organoleptik.

\section{Variabel penelitian}

Variabel yang diamati dalam penelitian ini yaitu sifat organoleptik dengan jumlah panelis 40 orang setengah terlatih.

1. Warna

2. Aroma

3. Keempukan

4. Tekstur

5. Citarasa

\section{Analisis data}

Data yang diperoleh dari masing-masing parameter mutu yang diukur diolah menggunakan program SPSS. Data tersebut dianalisa dengan analisis keragaman (ANOVA). Untuk perlakuan yang berbeda dilakukan pengujian dengan uji wilayah berganda (Duncan Multiple Range Test). (Steel dan Torrie, 1991).

\section{HASIL DAN PEMBAHASAN}

\section{Warna daging anjing}

Nilai rataan warna daging anjing dengan lama pemasakan yang berbeda dapat dilihat pada Tabel 2. Data tersebut memperlihatkan bahwa nilai rata-rata warna pada daging anjing terendah pada pemasakan 60 menit yaitu 4,77 (menarik) sedangkan tertinggi pada pemasakan 120 menit yaitu 5,57 (sangat menarik) dengan suhu pemasakan yang sama yaitu $85^{\circ} \mathrm{C}$. Warna merupakan salah satu indikator kualitas daging, meskipun warna tidak mempengaruhi nilai gizi (Nugraheni, 2011).

Hasil analisis sidik ragam
menunjukkan lama pemasakan
memberikan pengaruh berbeda sangat
nyata $(\mathrm{P}<0,01)$ terhadap warna daging
anjing. Hasil uji wilayah berganda Duncan
menunjukkan bahwa warna daging anjing
pada pemasakan 60 menit tidak berbeda
nyata dengan pemasakan 80 menit tapi

berbeda nyata dengan pemasakan 100 menit dan pemasakan 120 menit. Pemasakan 80 menit berbeda nyata dengan pemasakan 100 menit dan pemasakan 120 menit. Pemasakan 100 menit berbeda nyata dengan pemasakan 120 menit. Pemasakan 120 menit berbeda sangat nyata dengan pemasakan 60 menit dan 80 menit. Hal ini disebabkan karena adanya perubahan warna daging anjing saat pemasakan karena pada saat mentah daging anjing berwarna merah gelap, sehingga semakin lamanya pemasakan warna daging anjing akan menjadi coklat tua di tambah dengan adanya campuran bumbu/rempah saat pemasakan. Warna coklat pada daging anjing karena terjadinya reaksi maillard. Reaksi maillard adalah reaksi antara protein dan gula pereduksi (Rosiani et al. 2015). Kusnandar (2010) menyatakan bahwa reaksi maillard menghasilkan pigmen melanoidin yang bertanggung jawab pada pembentukan warna coklat dan reaksi karemelisasi menghasilkan warna coklat melalui reaksi kimia yang terjadi pada gula sederhana karena adanya proses pemanasan. Karena meskipun makanan tersebut lezat, tetapi bila penampilan tidak menarik waktu disajikan akan mengakibatkan selera orang yang mengkonsumsinya menjadi berkurang (Nurlaila et al., 2016). Sependapat dengan Susilo et al. (2014) waktu pemasakan yang belum optimal dapat menyebabkan warnakurang baik sehingga dapat menurunkan kriteria peminat.

\section{Aroma daging anjing}

Nilai rataan aroma daging anjing dengan lama pemasakan yang berbeda dapat dilihat pada Tabel 2. Data tersebut memperlihatkan bahwa nilai rata-rata aroma pada daging anjing terendah pada pemasakan 60 menit yaitu 4,35 (suka) sedangkan tertinggi pada pemasakan 120 menit yaitu 5,55 (sangat suka) dengan suhu pemasakan yang sama yaitu $85^{\circ} \mathrm{C}$. 
Tabel 2. Rataan Nilai Warna, Aroma, Keempukan, Tekstur, Citarasa Daging Anjing

\begin{tabular}{lcccc}
\hline \multirow{2}{*}{ Variabel } & \multicolumn{4}{c}{ Perlakuan } \\
\cline { 2 - 5 } & $\begin{array}{c}\text { P0 } \\
60 \text { Menit }\end{array}$ & $\begin{array}{c}\text { P1 } \\
80 \text { Menit }\end{array}$ & $\begin{array}{c}\text { P2 } \\
100 \text { Menit }\end{array}$ & $\begin{array}{c}\text { P3 } \\
120 \text { Menit }\end{array}$ \\
\hline Warna & $4,77^{\mathrm{a}}$ & $4,97^{\mathrm{a}}$ & $5,27^{\mathrm{b}}$ & $5,57^{\mathrm{c}}$ \\
Aroma & $4,35^{\mathrm{a}}$ & $4,67^{\mathrm{b}}$ & $5,20^{\mathrm{c}}$ & $5,55^{\mathrm{d}}$ \\
Keempukan & $5,10^{\mathrm{a}}$ & $5,27^{\mathrm{a}}$ & $5,52^{\mathrm{b}}$ & $5,65^{\mathrm{b}}$ \\
Tekstur & $5,12^{\mathrm{a}}$ & $5,32^{\mathrm{b}}$ & $5,57^{\mathrm{c}}$ & $5,75^{\mathrm{c}}$ \\
Citarasa & $5,00^{\mathrm{a}}$ & $5,07^{\mathrm{a}}$ & $5,45^{\mathrm{b}}$ & $5,67^{\mathrm{b}}$ \\
\hline
\end{tabular}

Keterangan: Superskrip yang berbeda pada kolom yang sama artinya berbeda sangat nyata $(\mathrm{P}<0,01)$

\begin{tabular}{lcrr}
\multicolumn{1}{c}{ Hasil } & analisis & sidik & ragam \\
menunjukkan & lama & pemasakan \\
memberikan & pengaruh berbeda & sanga
\end{tabular} memberikan pengaruh berbeda sangat Hasil uji berganda Duncan menunjukkan bahwa aroma daging anjing pada pemasakan 60 menit berbeda nyata dengan pemasakan 80 menit dan pemasakan 100 menit bahkan pemasakan 120 menit. Pemasakan 80 menit berbeda nyata dengan pemasakan 100 menit dan pemasakan 120 menit. Pemasakan 100 menit berbeda nyata dengan pemasakan 120 menit. Pemasakan 120 menit berbeda sangat nyata dengan pemasakan 60 menit dan pemasakan 80 menit. Karena waktu pemasakan yang belum terlalu lama menyebabkan, bumbu/rempah dan daging belum mengeluarkan aroma yang tajam. Selama pemanasan daging terjadi reaksi-reaksi yang kompleks yang melibatkan senyawa amino yang berkontribusi terhadap aroma daging. Aroma daging juga dapat dipengaruhi oleh jenis daging, lama pemasakan, dan temperatur suhu pemasakan (Nasution et al, 2016). Sebelum dimakan biasanya konsumen terlebih dahulu mencium aroma dari produk tersebut layak atau tidaknya produk tersebut untuk dikonsumsi adanya bahan komponen karbonil yang terbentuk selama proses pemasakan dapat bereaksi dengan amin, dan protein yang menghasilkan flavor yang diinginkan. Karena daging pada umumnya memiliki sifat yang mudah rusak sehingga perlu dilakukan pengolahan umtuk mempertahankan nilai gizi (Afrianti et al. 2013). Manusia dapat mencium bau yang keluar dari makanan karena adanya sel-sel epitel alfaktori dari bagian dinding atas rongga hidung yang peka terhadap bau. (Mastuti, 2008).

\section{Keempukan daging anjing}

Nilai rataan keempukan daging anjing dengan lama pemasakan yang berbeda dapat dilihat pada Tabel 1. Data tersebut memperlihatkan bahwa nilai ratarata keempukan pada daging anjing terendah pada pemasakan 60 menit yaitu 5,10 (empuk) sedangkan tertinggi pada pemasakan 120 menit yaitu 5,65 (sangat empuk) dengan suhu pemasakan yang sama yaitu $85^{\circ} \mathrm{C}$. bahwa pemasakan yang lama dan suhu tertentu memberikan suatu hasil bahwa nilai keempukan daging berbeda sangat nyata (Nikmaram et al., 2011).

Hasil analisis sidik ragam menunjukkan lama pemasakan memberikan pengaruh berbeda sangat nyata $(\mathrm{P}<0,01)$ terhadap keempukan daging anjing. Menurut Sudrajat (2015) lama pemasakan akan mempengaruhi kualitas daging karena panas akan menguapkan air, mendegradasi protein, dekomposisi asam amino, dan mengakibatkan jaringan ikat mengalami pengembangan sehingga membuat daging semakin empuk, dan 
daging semakin jus. Suhu dan lama pemasakan memegang peran peting pada perubahan jaringan ikat pada daging. Daging dengan potensi keempukan yang tinggi memerlukan suhu pemasakan dan waktu pemasakan yang cepat. Sebaliknya pada daging yang memperlihatkan kekerasan memerlukan waktu pemasakan yang cukup lama (Wowor et al., 2014).

Hasil uji wilayah berganda Duncan menunjukkan bahwa keempukan daging anjing pada pemasakan 60 menit tidak berbeda nyata dengan pemasakan 80 menit tetapi berbeda nyata dengan pemasakan 100 menit dan pemasakan 120 menit. Pemasakan 80 menit berbeda nyata dengan pemasakan 100 menit dan pemasakan 120 menit. Pemasakan 100 menit tidak berbeda nyata dengan pemasakan 120 menit. Pemasakan 120 menit berbeda sangat nyata dengan pemasakan 60 menit dan pemasakan 80 menit. Pemasakan yang lama akan mempengaruhi keempukan daging, dengan meningkatnya waktu pemasakan maka pembebasan cairan daging akan menjadi lebih besar sampai pengkerutan. Sudrajat (2015) bahwa perlakuan pemasakan akan mempengaruhi kualitas daging, karena panas akan menguapkan air, mendegradasi protein, dekomposisi asam amino dan mengakibatkan jaringan ikat mengalami pengembangan sehingga akan menambah keempukan dan kesan jus daging. Daging yang paling empuk adalah daging yang paling dicari konsumen.

\section{Tekstur daging anjing}

Nilai rataan tekstur daging anjing dengan lama pemasakan yang berbeda dapat dilihat pada Tabel 1. Data tersebut memperlihatkan bahwa nilai rata-rata tekstur pada daging anjing terendah pada pemasakan 60 menit yaitu 5,12 (halus) sedangkan tertinggi pada pemasakan 120 menit yaitu 5,75 (sangat halus) dengan suhu pemasakan yang sama yaitu $85^{\circ} \mathrm{C}$. karena singkatnya lama pemasakan memberikan tekstur yang kurang kenyal (Aristawati et al., 2013). Sependapat dengan Susilo et al. (2014) bahwa daging kulit dan tulang yang dimasak cepat atau dengan waktu yang singkat akan terlalu keras.

Hasil analisis sidik ragam menunjukkan lama pemasakan memberikan pengaruh berbeda sangat nyata $(\mathrm{P}<0,01)$ terhadap tekstur daginganjing. Lama pemasakan mempengaruhi tekstur daging karena struktur daging yang sebagian besar terdiri dari protein dan jaringan ikat sangat berperan penting dalam menentukan tekstur daging, sehingga semakin lama pemasakan tekstur pada daging akan disukai. Hasil uji wilayah berganda Duncan menunjukkan bahwa tekstur daging anjing pada pemasakan 60 menit berbeda nyata dengan pemasakan 80 menit dan pemasakan 100 menit bahkan pemasakan 120 menit. Pemasakan 80 menit berbeda nyata dengan pemasakan 100 menit dan pemasakan 120 menit. Pemasakan 100 menit tidak berbeda nyata dengan pemasakan 120 menit. Tetapi pemasakan 120 menit berbeda sangat nyata dengan pemasakan 60 menit dan pemasakan 80 menit. Hal ini disebabkan karena tekstur daging mulai nampak pada permulaan pemasakan pada menit 30 sampai 40 dan tekstur semakin meningkat dengan lamanya waktu pemasakan dimana lama waktu pemasakan mempengaruhi pelunakan kolagen (Nashar et al., 2012). Tekstur daging sangat mempengaruhi persepsi konsumen dalam menilai mutu daging. Kesan tekstur daging melibatkan tiga aspek berikut: kemudahan penetrasi gigi ke dalam daging, kemudahan pengunyahan menjadi potongan-potongan yang lebih kecil dan jumlah residu/sisa tertinggal setelah pengunyahan (Bouton et al. 1972). Hal ini menunjukan bahwa semakin bertambahnya lama pemasakan akan menaikan nilai tekstur daging (Nazhar et al. 2012).

\section{Citarasa daging anjing}


Nilai rataan citarasa daging anjing dengan lama pemasakan yang berbeda dapat dilihat pada Tabel 2. Data tersebut memperlihatkan bahwa nilai rata-rata citarasa daging anjing terendah pada pemasakan 60 menit yaitu 5,00 (enak) sedangkan tertinggi pada pemasakan 120 menit yaitu 5,67 (sangat enak) dengan suhu pemasakan yang sama yaitu $85^{\circ} \mathrm{C}$.

Hasil analisis sidik ragam menunjukkan lama pemasakan memberikan pengaruh berbeda sangat nyata $(\mathrm{P}<0,01)$ terhadap citarasa daging anjing. Hal ini disebabkan karena lamanya waktu pemasakan sangat mempengaruhi bumbu-bumbu yang masuk ke dalam daging sehingga daging menjadi semakin enak. (Setyaningsih et al, 2010) menyatakan bumbu/rempah yang dimasak dengan waktu yang lama dalam proses pengolahan daging dapat memberikan rasa pedas, gurih, dan enak sehingga disukai oleh konsumen. Hasil uji wilayah berganda Duncan menunjukkan bahwa citarasa daging anjing pada pemasakan 60 menit tidak berbeda nyata dengan pemasakan 80 menit tetapi berbeda nyata dengan pemasakan 100 menit dan pemasakan 120 menit. Pemasakan 80 menit berbeda nyata dengan pemasakan 100 menit dan pemasakan 120 menit. Pemasakan 100 menit tidak berbeda nyata dengan pemasakan 120 menit. Pemasakan 120 menit berbeda sangat nyata dengan pemasakan 60 menit dan pemasakan 80 menit. Panelis lebih menyukai daging anjing yang dimasak selama 120 menit. Tinangon et al. (2014) menyatakan bahwa penggunaan rempah pada umumnya akan meningkatkan aroma dan citarasa pada pangan olahan. Karena flavor utama olahan berupa komponen-komponen volatil maupun nonvolatil berpengaruh besar terhadap penerimaan daging olahan, Citarasa merupakan salah satu faktor yang mempengaruhi konsumen dalam suatu produk makanan (Aristawati et al., 2013). Sehingga dapat disimpukan lama waktu pemasakan membuat penetrasi bumbu semakin meresap ke dalam daging sehingga daging semakin enak.

\section{KESIMPULAN}

Secara keseluruhan lama pemasakan daging RW secara organoleptik dapat diterima namun lama pemasakan 120 menit lebih disukai dan diterima oleh panelis.

\section{DAFTAR PUSTAKA}

Afrianti, M., B. Dwikola dan B.E. Setiani. 2013. Perubahan warna, profil protein dan mutu organoleptik daging ayam broiler setelah di rendam dengan ekstrak daun senduduk. Jurnal Aplikasi Teknologi Pangan 2(3): 116-120.

Anggreani. P 2018. Lima Daerah Di Indonesia Pemakan Daging Anjing. Editor Sri kurnia Mahiruni.

Aristawati, R.W., W. Atmaka, D.R.A. Muhammad. 2013. Subtitusi tepung tapioka (manihop esculenta) dalam pembuatan Takoyaki. Jurnal Teknosains Agointek 2(1): 5665.

Bouton, P.E., P.V. Haris dan W. R Shothos. 1972. The affects of cooking temperature and time on some mechanical properties of meat. J. Food Sci. 97: 140-144.

Kusnandar, F., 2010. Mengenai sifat lemak dan minyak, Departemen ilmu teknologi pangan IPB. http//itp.fateta.ipb.ac.id/id.dia kses: 10 Desember 2020.

Lumbong, R., R. M. Tinangon, M. D. Rotinsulu, dan J. A. D. Kalele. 2017. Sifat organoleptik burger ayam dengan metode memasak yang berbeda. Jurnal Zootek 37(2): 252258

Mastuti, R. 2008. The effects of frying temperature and time on the phisycal and chemical qualiityes 
of the restructured goat meat trimming. Jurnal Ilmu dan Teknologi Hasil Ternak 3(2): 23-31.

Nashar, V., R. Billy, D. Rosyidi dan A.S. Widati. 2012. Pengaruh lama pemanggangan dalam microwave terhadap kualitas fisik steak daging. Jurnal Ilmu dan Teknologi Hasil Ternak 7(1): 6-11

Nasution, A.F., E. Dihansi, dan Anggreani. 2016. Pengaruh subtitusi pakan`komersial dengan tepung ampas kelapa terhadap sifat fisik dan organoleptik daging ayam kampong. Jurnal Pertanian 7(1): 1422.

Nugraheni, M. 2011. Potensi makanan formentasi sebagai makanan fungsional. Jurnal Pendidikan Teknik Boga Busa 6 (1):

Nurlaila, N., A. Sukaina, A. Amirudin. 2016. Pengembangan produk sosis fungsional berbahan ikan tenggiri (scomberomorur Sp.) dan tepung daun kelor (moringa oleivera $L$ ). Jurnal Pendidikan Teknologi Pertanian 2(2): 105-113.

Nikmaram, P., M.S. Yarmand, Z. Emamjomeh dan H. K. Darehabi 2011. The effect cooking methods on textural and microstructure properties of veal muscle (longissimus dorsi). Jurnal global veterinaria 6 (2): 201207.

Rompis, J. E. G., dan S. Komansilan 2014. Efektivitas cara pemasakan terhadap karakteristik fisik makanan daging babi hutan. Jurnal zootek 34(2):6570.

Rosiani, N., W.E. Basito, E. Widowati. 2015. Kajian karakteristiksensoris fisik dan kimia kerupuk fortifikasi daging lidah buaya Aloevera) dengan metode pemanggangan menggunakan Microwave. Jurnal Teknologi Hasil Pertanian 8(2): 8498
Setyaningsi, D., A. Aprianto, M.P. Sari. 2010. Analisis Sensori Untuk Industry Pangan Dan Agro. Bogor: IPB pess.

Sudrajat, A. 2015. Pengaruh Temperatur Lama Pemasakan Terhadap Karakteristik Fisik Dan Organoleptik Daging. Skripsi. Fakultas Peternakan, Universitas Sebelas Maret, Surakarta.

Susilo, T.W., P.H. Riadi dan A.D. Anggo. 2014. Pengaruh waktu pengukusan terhadap kualitas ikan petek (Leiognathus splendens) presto menggunakan alat "TTSR". Jurnal Pengolahan Dan Bioteknologi Hasil Perikanan 3(2):75-81.

Steel, R. D. and Torrie. J, K. 1991. Prinsip Dan Prosedur Stastistika. PT. Gramedia Pusaka Utama, Jakarta.

Tinangon, R., D. Rosyidi. L. Radiyati dan Purwadi. 2014. The influence of clove addition on phisicochemical and organoleptical charakteritics of buger meat. Scholars Journal of Enginnering and Technologi 2(6B): 886-889.

Wowor, A.K.Y., T.A. Ransaleleh, M. Tamansoleng dan S. Komansilan. 2014. Lama penyimpanan pada suhu dingin daging broiler yang diberi air perasan jeruk Kasturi (citrus madurensis lour). Jurnal Zootek 34(2): 148-158 